\title{
PENGENDALIAN PERALATAN RUMAH TANGGA MENGGUNAKAN ARDUINO UNO BERBASIS BLUETOOTH
}

\author{
Ahmad Fauzi \\ Teknik Elektro, Teknik, Universitas Hasym asy’ari , Email : fauzi_ahmad.7@yahoo.com \\ Tri Rijanto \\ Teknik Elektro, FakultasTeknik, Universitas Hasym asy’ari , Email: Tririjanto@unesa.ac.id

\section{Humaidillah Kurniadi Wardana} \\ Teknik Elektro, Fakultas Teknik, Universitas Hasym asy’ari, Email: bhindere.adi3@gmail.com
}

\section{Abstrak}

Dengan bertambahnya kesibukan manusia dibutuhkan sebuah inovasi sistem rumah pintar yang merupakan konsep rumah automation yang terdiri dari perangkat kontrol dari smartphone. Sistem rumah pintar bertujuan untuk memudahkan pekerjaan manusia dalam mengontrol peralatan rumah tangga dengan mengunakan smartphone. Metode penelitian yang digunakan adalah metode pengukuran jarak yang dijangkau.

Pada sensor Light Dependent Resistor (LDR) dengan metode pembacaan rata-rata intensitas cahaya pada pagi hari dan sore hari. Metode pada sensor Passive Infrared Receaver (PIR) dengan mendeteksi respon jarak kepekaan pergerakkan manusia.

Hasil penelitian menunjukkan jarak yang dapat dijangkau oleh bluetooth hc-05 untuk mengontrol lampu dan kipas sejauh 75 meter dengan kondisi tanpa penghalang, sedang sensor LDR dengan rata-rata 20,5 lux pada pagi hari sedangkan pada sore hari dengan rata-rata 19,5 lux, sensor PIR merespon gerakan manusia sejauh 7 meter.

Kata Kunci: Bluetooth hc-05, Rumah Pintar, Sensor Light Dependent Resistor (LDR), Sensor Passive Infrared Receaver (PIR).

\section{Abstract}

With increasing preoccupation of mankind it takes a smart home system innovation which is the concept of home automation control device comprising of a smartphone. Smart home system aims to facilitate the work of humans in controlling household appliances using a smartphone.

The research method used is the method of measurement of the distance to reach. On the sensor Light Dependent Resistor (LDR) and method of reading the average light intensity on the morning and afternoon. A method of Passive Infrared sensor on Receaver (PIR) by detecting the distance sensitivity of human movement response.

The results showed the distance which can be reached by a hc-05untuk bluetooth to control the lights and the fan as far as 75 metres to condition without hindrance, while sensors LDR with an average 20.5 lux in the morning while in the evening with an average 19.5 lux, sensor PIR respond to human movement as far as 7 meters.

Keywords: Bluetooth hc-05, Smart home, Sensor Light Dependent Resistor (LDR), Infrared Sensor Receaver (PIR).

\section{PENDAHULUAN}

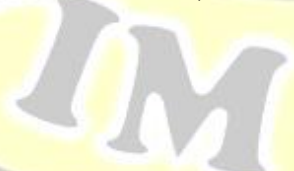

Perkembangan teknologi dengan memadukan antara aplikasi elektronika pada peralatan rumah tangga dan kontrol jarak jauh menggunakan smartphone akhir-akhir ini semakin pesat perkembangannya. Teknologi yang memanfaatkan inovasi keduanya disebut dengan teknologi smart home atau disebut dengan rumah pintar.

Smart home merupakan sebuah teknologi rumah pintar untuk tempat tinggal yang menghubungkan jaringan komunikasi dengan peralatan listrik untuk dikontrol, dimonitor atau diakses dari jarak jauh.
Sistem rumah cerdas (smart home) merupakan sistem aplikasi yang mengunakan gabungan antara teknologi dan pelayanan untuk dikhususkan pada lingkungan rumah dengan fungsi tertentu yang bertujuan meningkatkan efisiensi, kenyamanan dan keamanan penghuninya (Azka, 2014).

Dengan memperhatikan kondisi tersebut maka diperlukan sistem otomatisasi pada peralatan rumah tangga sehingga dapat memberikan kemudahan dan kenyamananan bagi penghuni rumah. Salah satu perkembangan yang dapat digunakan untuk smart home 
adalah dengan memanfaatkan teknologi wireless seperti bluetooth yang sudah tersedia di smartphone, yang nantinya berkomunikasi data dengan modul bluetooth HC-05. Modul bluetooth HC-05digunakan sebagai sarana koneksi untuk mengendalikan arduino uno sebagai sistem pengontrol dan relay mengendalikan perangkat listrik. Bluetooth dipilih sebagai media kontrol karena tidak memerlukan biaya tambahan ketika pengoperasian berlangsung. Pemanfaatan bluetooth pada smartphone yang berfungsi sebagai remote kontrol untuk mengendalikan sistem otomasi pada peralatan

Maka dari itu perlu melakukan perancangan dan pembuatan pengendali peralatan rumah tangga menggunakan arduino uno dengan konektivitas bluetooth. Penelitian ini memiliki keunggulan diantaranya adalah smartphone dalam hal ini adalah smartphone android yang dapat mengendalikan beberapa peralatan elektronik yaitu 4 (empat) lampu dan kipas. Untuk lampu luar ruangan (teras) dikontrol menggunakan sensor Light Dependent Resistor (LDR). Lampu kamar mandi dikontrol menggunakan sensor Passive Infrared Receaver (PIR).

\section{METODE}

Penelitian yang dilakukan merupakan jenis penelitian rekayasa atau rancang bangun, rancangan yang dimaksud adalah ruang bangun di bidang kelistrikan.

Perancangan alat penelitian ini secara umum akan diselesaikan dengan tahapan seperti pada Gambar 1 di bawah ini:

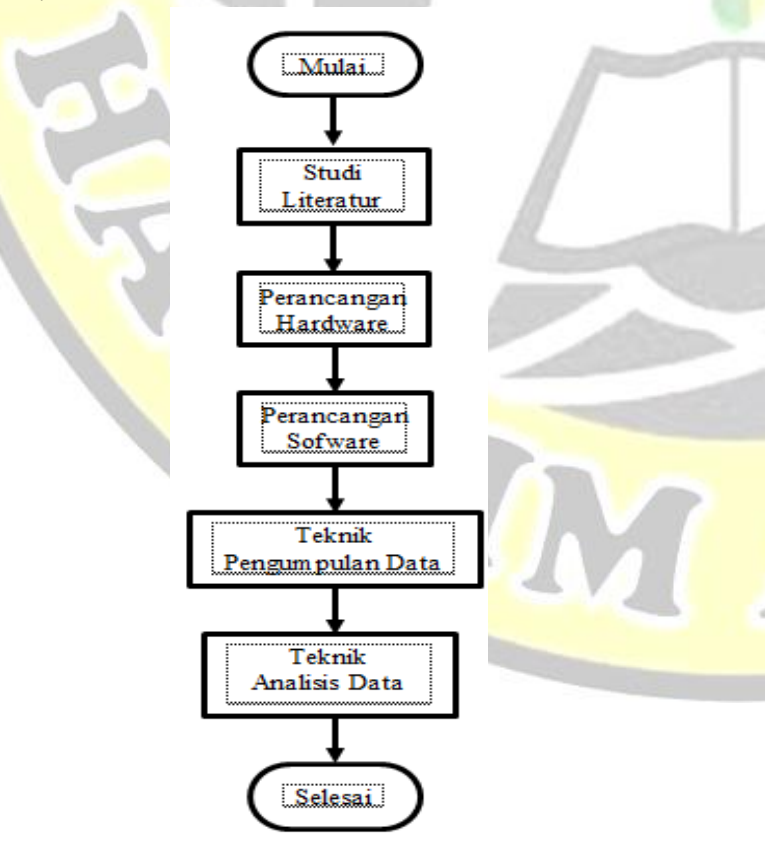

Gambar 1. Diagram Blok Rancangan Penelitian

Dari diagram blok pada Gambar 3.1 maka prosedur untuk masing-masing tahapan penelitian akan dijelaskan sebagai berikut:

\section{Studi Literatur}

Sebelum mengerjakan penelitian ini, peneliti menelaah beberapa penelitian yang masih berhubungan baik. Dari beberapa penelitian tersebut akan ditemukan suatu rumusan masalah. Pengajuan pertanyaanpertanyaan penelitian yang jawabannya harus dicari menggunakan data yang relevan. Kemudian peneliti perlu menetapkan informasi-informasi yang diperlukan untuk menjawab pertanyaan-pertanyaan yang telah dirumuskan. Sebagai bahan literatur peneliti mempelajari buku-buku manual dan jurnal-jurnal tentang pengendalian peralatan rumah tangga menggunakan arduino uno berbasis bluetooth, atau jurnal-jurnal tentang smart home.

\section{Perancangan Hardware}

Proses pembuatan alat hardware, pengendalian peralatan rumah tangga rumah tangga.menggunakan arduino uno berbasis bluetooth. Pembuatan alat ini menggunakan modul bluetooth HC-05, modul sensor gerak (PIR) dan modul sensor cahaya (LDR) sebagai inputan, mikrokontroler arduino uno digunakan sebagai sistem pemroses data, dan modul relay 8 channel sebagai output. berikut ini adalah rangkaian skematik dan blok diagram alat kontrol peralatan rumah tangga dengan bloetooth HC-05 seperti Gambar 1 di bawah ini:

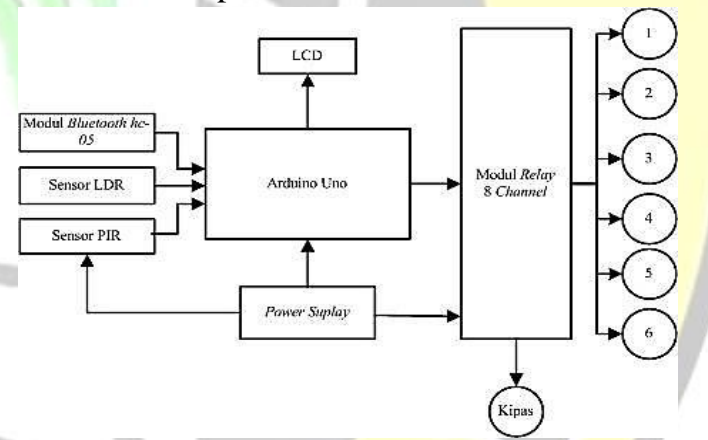

Gambar 2. Diagram Blok Hardware

Keterangan:

1. Modul bluetooth HC-05 berfungsi sebagai penerima perintah yang dikirimkan oleh smartphone.

2. Modul sensor LDR berfungsi sebagai sensor cahaya.

3. Modul sensor PIR berfungsi sebagai sensor gerak.

4. Mikrokontroler Arduino Uno berfungsi sebagai pengolah atau pemroses data.

5. Simbol no. 1 menunjukan lampu ruangan tamu

6. Simbol no. 2 menunjukan lampu kamar depan.

7. Simbol no. 3 menunjukan lampu kamar belakang.

8. Simbol no. 4 menunjukan lampu ruangan dapur.

9. Simbol no. 5 menunjukan lampu kamar mandi yang di kontrol menggunakan modul sensor gerak (PIR).

10. Simbol no. 6 menunjukan lampu teras (luar ruangan) yang di kendalikan menggunakan modul sensor cahaya (LDR). 


\section{Pengendalian Peralatan Rumah Tangga Menggunakan Arduino Uno Berbasis Bluetooth}

11. Kipas berfungsi sebagai pendingin ruangan

12. LCD berfungsi untuk menampilkan data.

13. Power supply sebagai penyuplai sumber tegangan.

Gambar 2 merupakan rancangan simulasi dari pengendalian peralatan rumah tangga mengunakan arduino uno berbasis bluetooth:

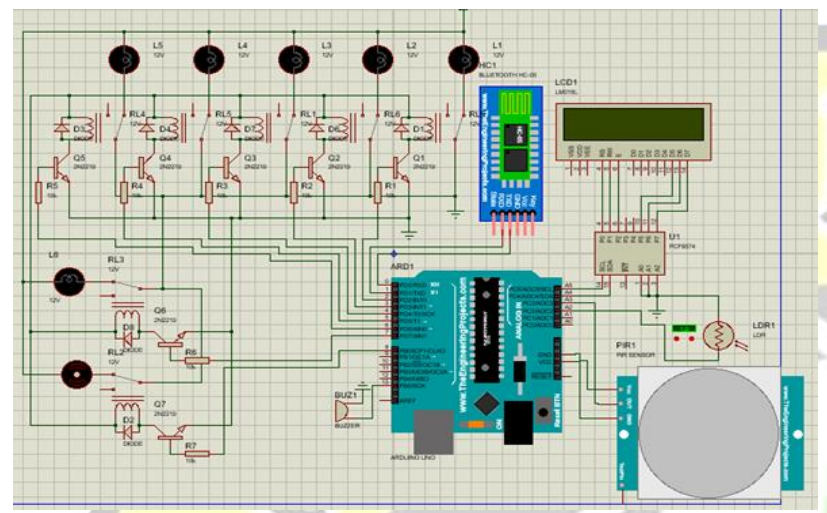

Gambar 3. Rangkaian Skematik

\section{Perancangan Perangkat Lunak Software}

Aplikasi android untuk di handphone sebagai pengendali dan penerima dibuat dengan menggunakan App Spp Pro. App Spp Pro adalah sebuah tool untuk membuat aplikasi android. Kelebihan dari tool ini adalah karena berbasis visual block programming, artinya bisa membuat aplikasi tanpa kode satupun. Disebut visual block programming karena dari tool ini dapat melihat, menggunakan, menyusun dan drag-drops yang merupakan blok simbol-simbol perintah dan fungsi event handler tertentu dalam membuat aplikasi, dan dapat menyebutnya tanpa menuliskan kode program coding less. Contoh tampilan aplikasi App Spp Pro seperti pada Gambar 3 di bawah ini: triplek dengan ukuran panjang $\times$ lebar $\times$ tinggi $=35 \mathrm{~cm} \times$ $27,5 \mathrm{~cm} \times 24 \mathrm{~cm}$ dengan bahan sebagai berikut:

Papan triplek dengan ketebalan $0.5 \mathrm{~cm}$ sebagai pengganti tembok pada Prototipe rumah pintar yang sesungguhnya, kertas asturo sebagai pelapis dinding pada Prototipe rumah pintar, mika dengan ukuran panjang $\times$ lebar $=35 \mathrm{~cm} \times 27,5 \mathrm{~cm}$ sebagai penutup atap pada Prototipe rumah pintar.

Berikut ini adalah hasil pembuatan Prototipe rumah pintar pada Gambar 5(a) tampak depan, Gambar 5(b) tampak samping kanan dan Gambar 5(c) tampak kiri sebagai berikut:

Gambar 5(a). Tampak Depan Prototipe Rumah Pintar

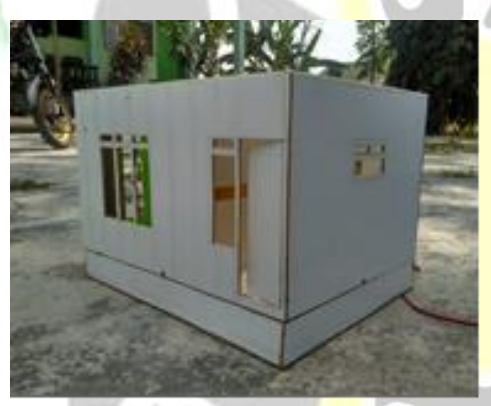

Gambar 5(b). Tampak dari Samping Kanan Prototipe Rumah Pintar

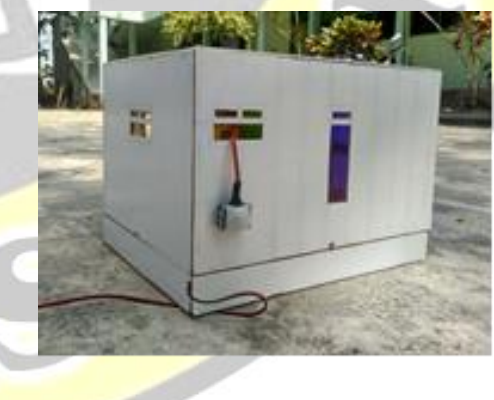

Gambar 5(c). Tampak dari Samping Kiri Prototipe Rumah Pintar

Gambar 4. Blok Program pada Bluetooth Spp Pro

\section{HASIL DAN PEMBAHASAN \\ Prototipe Rumah Pintar}

Prototipe rumah pintar atau arketipe adalah bentuk awal, contoh sistem pengendalian peralatan rumah tangga (smart home) dengan standar ukuran dari sebuah entitas. Prototipe rumah pintar di buat menggunakan papan
Dalam Prototipe rumah pintar ada enam ruangan yang di kendalikan, berikut adalah ruangan pada Prototipe rumah pintar di tunjukan pada Gambar 6 di bawah ini: 


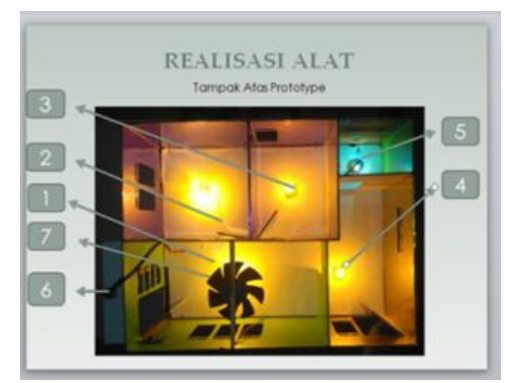

Gambar 6. Ruangan pada Prototipe Rumah Pintar

Keterangan:

1. Ruang Tamu

2. Kamar Depan

3. Kamar Belakang

4. Ruang Dapur

5. Kamar Mandi

6. Teras (Luar Ruangan)

7. Kipas Ruangan Tamu

\section{Pembuatan dan Rangkaian Sistem Rumah Pintar}

Rangkaian sistem pengendalian peralatan rumah tangga pada Prototipe rumah pintar sesuai pada Gambar 7 di bawah ini:

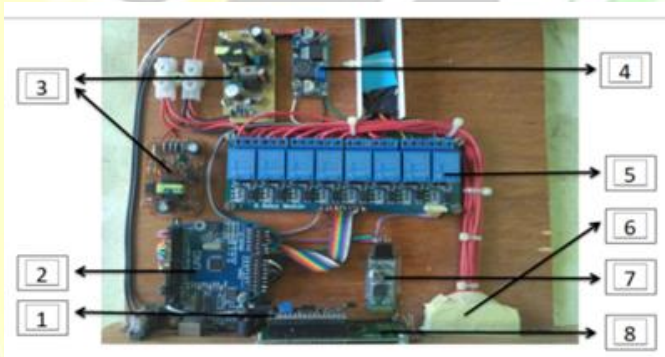

Gambar 7. Rangkaian Prototipe Rumah Pintar

Keterangan:

1. Inter-integrated circuit (I2C) pada pin SCL dan SDA

2. Arduino uno

3. Adaptor 12 volt 2 Ampere dan 9 volt 1 Ampere

4. Penurun Tegangan (Step Down) 12 volt ke 5 volt

5. Modul Relay 8 Channel pada pin D2 sampai D9

6. Saklar Manual

7. Modul Bluetooth HC-05 pada pin D0 (RX) dan D1 (RT)

8. Liquid Cristal Display (LCD) $16 \times 2$ pada pin I2C

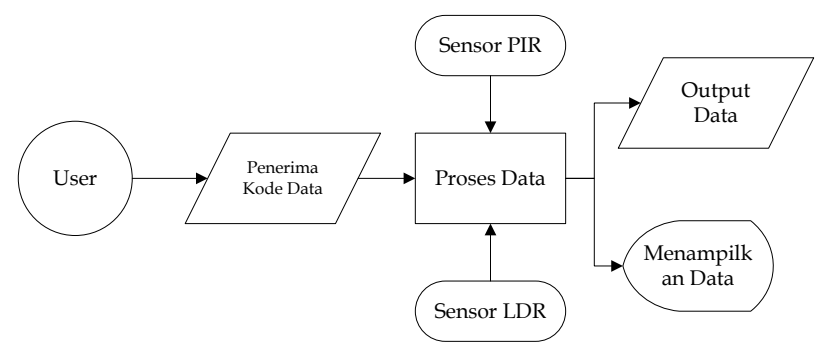

Gambar 8. Cara Kinerja Rumah Pintar
Hasil Pengujian Jarak Pada Modul Bluetooth HC-05

Pengujian sistem pengendali lampu dan kipas pada peralatan rumah tangga. pengujian jarak pada module bluetooth HC-05, pada tabel terdapat sampel ruangan yang akan diuji. Apabila kondisi awal ruangan off dan jika diperintahkan untuk menyalakan (on) maka kondisi lampu akan on sesuai dengan perintah user. Hasil pengujian jarak terdapat pada Tabel 1 di bawah ini:

Tabel 1 Hasil Pengujian Jarak Modul Bluetooth HC-

\begin{tabular}{|c|c|c|c|c|c|c|c|}
\hline $\begin{array}{l}N \\
0\end{array}$ & $\begin{array}{l}\text { Sampel } \\
\text { Ruangan }\end{array}$ & $\begin{array}{l}\text { Kondisi } \\
\text { Awa1 }\end{array}$ & $\begin{array}{c}\text { Perintah } \\
\text { pada } \\
\text { Smartphone }\end{array}$ & $\begin{array}{l}\text { Kondisi } \\
\text { Akhir }\end{array}$ & $\begin{array}{c}\text { Waktu } \\
\text { Jeda } \\
\text { (Detik) }\end{array}$ & $\begin{array}{c}\text { Jarak } \\
\text { (Meter) }\end{array}$ & Keterangan \\
\hline 1 & R. Tamu & Mati & On & Nyala & 00.65 & 5 & Terkoneksi \\
\hline 2 & R. Tamu & Nyala & Off & Mati & 00.82 & 10 & Terkoneksi \\
\hline 3 & R. Tamu & Mati & $\mathrm{O}_{n}$ & Nyala & 00.77 & 15 & Terkoneksi \\
\hline 4 & K. Depan & Nyala & Off & Mati & 00.82 & 20 & Terkoneksi \\
\hline 5 & K. Depan & Mati & $\mathrm{On}$ & Nyala & 00.57 & 25 & $\begin{array}{l}\text { Terkoneksi } \\
\end{array}$ \\
\hline 6 & K. Depan & Nyala & Off & Mati & 00.55 & 30 & Terkoneksi \\
\hline 7 & K. Belakang & Mati & $O_{n}$ & Nyala & 00.96 & 35 & Terkoneksi \\
\hline 8 & K. Belakang & Nyala & Off & Mati & 00.70 & 40 & Terkoneksi \\
\hline 9 & K. Belakang & Mati & $O_{n}$ & Nyala & 00.87 & 45 & Terkoneksi \\
\hline 10 & R. Dapur & Nyala & Off & Mati & 00.75 & 50 & Terkoneksi \\
\hline 11 & R. Dapur & Mati & On & Nyala & 00.79 & 55 & Terkoneksi \\
\hline 12 & R. Dapur & $\begin{array}{l}\text { Nyala } \\
\text { yat }\end{array}$ & Off & Mati & 00.75 & 60 & $\begin{array}{l}\text { Terkoneksi } \\
\end{array}$ \\
\hline 13 & Kipas & Mati & $\mathrm{O}_{n}$ & Nyala & 00.81 & 65 & Terkoneksi \\
\hline 14 & Kipas & Nyala & Off & Mati & 00.93 & 70 & Terkoneksi \\
\hline 15 & Kipas & Mati & $O_{n}$ & Nyala & 00.64 & 75 & Terkoneksi \\
\hline 16 & R.Tamu & Nyala & Off & Mati & 00.70 & 78 & Terkoneksi \\
\hline 17 & R.Tamu & Mati & On & Mati & - & so & $\begin{array}{c}\text { Tidak } \\
\text { Terkoneksi }\end{array}$ \\
\hline
\end{tabular}

Dapat disimpulkan Tabel 1 di atas hasil pengujian jarak maksimum yang terkoneksi bluetooth HC-05 dengan smartphone sejauh 78 meter dengan kondisi tanpa penghalang. Respon kepekaan bluetooth HC-05 tercepat dengan waktu 00,55 detik sedangkan respon paling lambat dengan waktu 00,96, detik.

\section{Hasil pengujian Sensor LDR}

Kinerja sensor Light Dependent Resistor (LDR) dalam melakukan koneksitas pada lampu luar ruangan (teras). Tabel 2 di bawah ini adalah hasil dari pengujian sensor Light Dependent Resistor (LDR).

\section{Cara Kerja Sistem Rumah Pintar}

Tabel 2 Hasil Pengujian Sensor Light Dependent

Berikut alur cara kerja pada Prototipe rumah pintar pada Gambar 4.4 di bawah ini:

\begin{tabular}{|c|c|c|c|c|c|c|}
\hline \multicolumn{7}{|c|}{ Resistor (LDR) } \\
\hline No & Hari/tgl/thun & Waktu & $\mathrm{Jam}$ & $\begin{array}{l}\text { Kondisi } \\
\text { Lampu }\end{array}$ & $\begin{array}{c}\text { Insentitas } \\
\text { Cahaya } \\
\text { (Lux) }\end{array}$ & $\begin{array}{l}\text { Insentitas } \\
\text { Cahaya } \\
\text { (Candela) }\end{array}$ \\
\hline 1 & \multirow{2}{*}{$\begin{array}{c}\text { Sabtu. } \\
21 \text { Juli } 2018\end{array}$} & Pagi & 05.35 .55 & Mati & 20 & 4.15 \\
\hline 2 & & Sore & 17.38 .35 & Hidup & 18 & 3.74 \\
\hline 3 & \multirow{2}{*}{$\begin{array}{c}\text { Ahad, } \\
22 \text { juli } 2018\end{array}$} & Pagi & 05.34 .50 & Mati & 19 & 3.22 \\
\hline 4 & & Sore & 17.37 .42 & Hidup & 18 & 3.74 \\
\hline 5 & \multirow{2}{*}{$\begin{array}{c}\text { Senin, } \\
23 \text { juli } 2018\end{array}$} & Pagi & 05.35 .30 & Mati & 20 & 4.15 \\
\hline 6 & & Sore & 17.33 .09 & Hidup & 23 & 4.78 \\
\hline 7 & \multirow{2}{*}{$\begin{array}{c}\text { Selasa, } \\
24 \text { juli } 2018\end{array}$} & Pagi & 05.34 .30 & Mati & 22 & 4.57 \\
\hline 8 & & Sore & 17.35 .21 & Hidup & 29 & 6.02 \\
\hline
\end{tabular}




\section{Pengendalian Peralatan Rumah Tangga Menggunakan Arduino Uno Berbasis Bluetooth}

Dapat disimpulkan hasil pengujian sensor LDR yang dilakukan pada waktu pagi dan sore hari dengan pengujian selama 4 hari. didapatkan hasil rata-rata intensitas cahaya yang didapatkan oleh LDR pada waktu pagi hari sebesar 20,5 lux dengan kondisi lampu mati, seperti pada Gambar 8, dan rata-rata intensitas cahaya yang didapatkan oleh LDR pada waktu sore hari sebesar 19,5 lux dengan kondisi lampu nyala, seperti pada Gambar 9 di bawah ini:

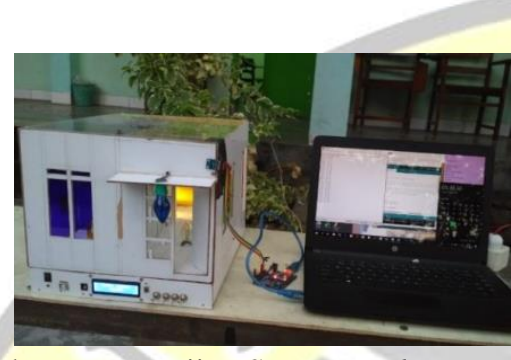

Gambar 9. Pengujian Sensor Light Dependent Resistor (LDR) pada Pagi Hari

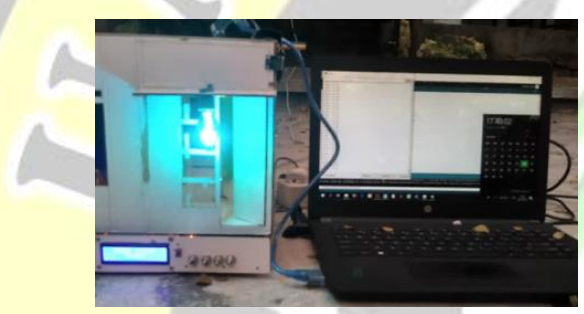

Gambar 10. Pengujian Sensor Light Dependent Resistor (LDR) pada Sore Hari

\section{Hasil Pengujian Sensor PIR}

Pengujian sensor PIR ini diuji melalui respon pergerakan manusia yang dapat di lihat seperti Gambar 10 di bawah ini:

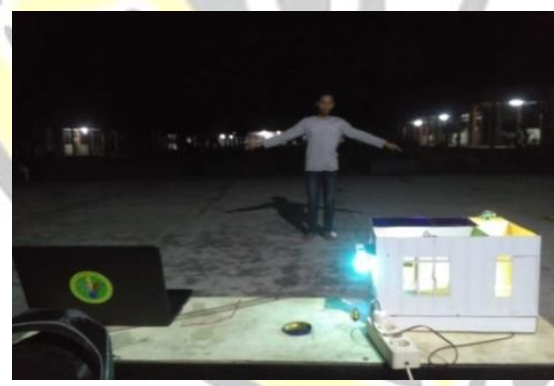

Gambar 10 .Pengujian Sensor PIR

Berikut hasil pengujian sensor PIR pada lampu kamar mandi. Berikut Tabel 3 di bawah ini:

Tabel 3 Hasil Analisa Sensor PIR

\begin{tabular}{|c|c|c|c|}
\hline No & $\begin{array}{c}\text { Jarak } \\
\text { Manusia } \\
\text { (Meter) }\end{array}$ & $\begin{array}{c}\text { Kondisi } \\
\text { Lampu }\end{array}$ & Keterangan \\
\hline 1 & 1 & Menyala & Dapat Merespon Gerakan \\
\hline 2 & 2 & Menyala & Dapat Merespon Gerakan \\
\hline 3 & 3 & Menyala & Dapat Merespon Gerakan \\
\hline 4 & 4 & Menyala & Dapat Merespon Gerakan \\
\hline 5 & 5 & Menyala & Dapat Merespon Gerakan \\
\hline
\end{tabular}

\begin{tabular}{|c|c|c|c|}
\hline 6 & 6 & Menyala & Dapat Merespon Gerakan \\
\hline 7 & 7 & Menyala & Dapat Merespon Gerakan \\
\hline 8 & 8 & Mati & $\begin{array}{c}\text { Tidak Dapat Merespon } \\
\text { Gerakan }\end{array}$ \\
\hline
\end{tabular}

Dari pengujian Tabel 3 di atas menunjukan bahwa jarak terjauh kepekaan sensor PIR yang dapat merespon suatu pergerakan adalan sejauh 7 meter.

\section{KESIMPULAN DAN SARAN}

\section{Kesimpulan}

Berdasarkan pada rumusan masalah yang ada sehingga dapat ditarik sebuah kesimpulan sebagai berikut:

1. Cara kerja sistem dalam pengendalian peralatan rumah tangga ini menggunakan arduino uno sebagai mikrokontroler yang di kendalikan oleh smartphone dengan menggunakan media transmisi bluetooth hc05. Jarak maksimum yang dapat terkoneksi oleh kedua perangkat tersebut sejauh 75 meter dengan kondisi pengujian tanpa penghalang.

2. Hasil pengujian rata-rata kepekaan cahaya sensor LDR dalam mengendalikan nyala intensitas lampu pada pagi sebesar 20,5 Lux dan pada sore hari sebesar 19,5 Lux selama 4 hari berturut -turut.

3. Hasil Pengujian jarak terjauh kepekaan sensor PIR terhadap suatu pergerakan manusia dalam menyalakan lampu kamar mandi sejauh 7 meter.

\section{Saran}

Adapun saran bagi peneliti yang ingin mengembangkan penelitian ini, antara lain:

1. Untuk pengujian alat pengendali peralatan rumah tangga menggunkan arduino uno berbasis bluetooth dilakukan apabila cuaca atau kondisi cuaca yang mendukung, agar data yang dikirim bluetooth tidak terlambat diterima oleh beluetooth hc-05.'

2. Untuk mengembangkan rumah pintar sebaiknya menggunakan modul GSM atau IOT supaya pengontrolan bisa dilakukan dengan jarak yang jauh dan tidak terbatas.

\section{DAFTAR PUSTAKA}

Aulia.2015. http://auliazikryoned.blogspot.co.id/2015/03/ perkembangan-gadget-di-indonesia.html. (Diakses pada tanggal 04 April 2018).

Azka, dkk. 2014. "Implementasi Radio Frequency Identification (Rfid) Sebagai Otomasi Pada Smart home" Padang : Politeknik Negeri Padang Universitas Andalas.

Azkia, Fatma. 2016. https://www.liputan6.com /properti/read/ 2444392/konsep-smart-home-dimata-arsitek. (Diakses pada tanggal 06 April 2018).

Diotama, dkk. 2014. "Sistem Smart House Berbasis Android sebagai Pengendali dan Pemantau 
Tangki Air dan Lampu Taman" ISSN : 22524908 Vol. 3 No. 3. Politeknik Negeri Semarang.

Hariri Santoso, 2015. https://apasihbedanya. blogspot.co.id/2015 /05/apa-perbedaan-arduinodan-raspberry-pi.html. (Diakses pada tanggal 04 April 2018).

Halwa. 2015. http://tetramultatisari.blogspot.com/2015 /11/ teknologi-smartphone_2.html. (Diakses pada tangal 01 Agustus 2018).

Kaur Surinder, et all.2016 "Home Automation And Security System" An International journal (ACII), Vol.3,No.3 New Delhi-110063, India.

Istianto, jazi eko. 2014 "Pengantar Elektronika dan Instrumentasi pendekatan Project Arduino dan Android" Andi Yogyakarta.

Martyn. 2015. http://www.martyncurrey.com/arduinowith- $h c-05$-bluetooth-module-in-slave-mode/ (Diakses pada tanggal 03 April 2018).

Miller,

$$
\text { Crystal. }
$$

http://www.nawandihalabja.com/light-dependen t-resistor-circuit-diagram/light-dependentresistor-circuit-diagram-new-13-best-dependentresistors-images-on-pinterest// (Di akses pada tanggal 04 april 2018).

Putra, anggi adi. 2018. http://robot-antik.blogspot.co.id /2014/11/mengenal-sekilas-mikrokontrolerarduino. html (Diakses pada tanggal 04 april 2018).

Raj, B.Aswinth. 2015 https://circuitdigest.com/article/ 16x2-lcd-display-module-pinout-datasheet (Diakses pada tanggal 04 april 2018).

Sadewo, dkk. 2017 "Perancangan Pengendalian Rumah menggunakan Smartphone Android dengan Koneksi Bluetooth" Jurnal pengembangan Teknologi Informasi dan Ilmu Komputer. Vol 1,No. 5 Hlm 415-425.Universitas Brawijaya.

Sur. 2014. "Mengidentifikasi Komponen Instalasi Listrik Rumah Tangga" http://sagaries.blogspot.co.id/ 2012/01/ mengidentifikasi-instalasi-listrik.html. (Diakses pada Tanggal 06 April 2018).

Sugiyono. 2000. Metodologi Penelitian. Bandung: Alvabeta.

Sutono. 2014. "Perancangan Sistem Aplikasi Otomatis Lampu Penerangan Menggunakan Sensor Gerak Dan Sensor Cahaya Berbasis Arduino Uno(ATMEGA 328)". Majalah Ilmiah UNICOM. Vol 12 No.2. Universitas Komputer Indonesia.

http://jurnal.unikom.ac.id/jurnal/perancangansistem-aplikasi.4e (Diakses pada Tanggal 03 April 2018).

Tribowo, dkk. 2013." "Prototype Sistem Penerangan Lampu Otomatis Menggunakan Ds 1307 Berbasis Mikrokontroler Atmega16" "Program Studi Teknik Elektronika, Politeknik Cilacap.

Tarun, agarwal 2018. https://www.elprocus.com/passiveinfrared-pir-sensor-with-applications/ (Diakses pada Tanggal 06 April 2018).

Yudhisbrow. 2017. "Pengertian Android Menurut Para Ahli” https://galleryteknologi.wordpress.com /2017/05/19/pengertian-android-menurut-paraahli/. (Diakses pada tanggal 01 Agustus 2018).

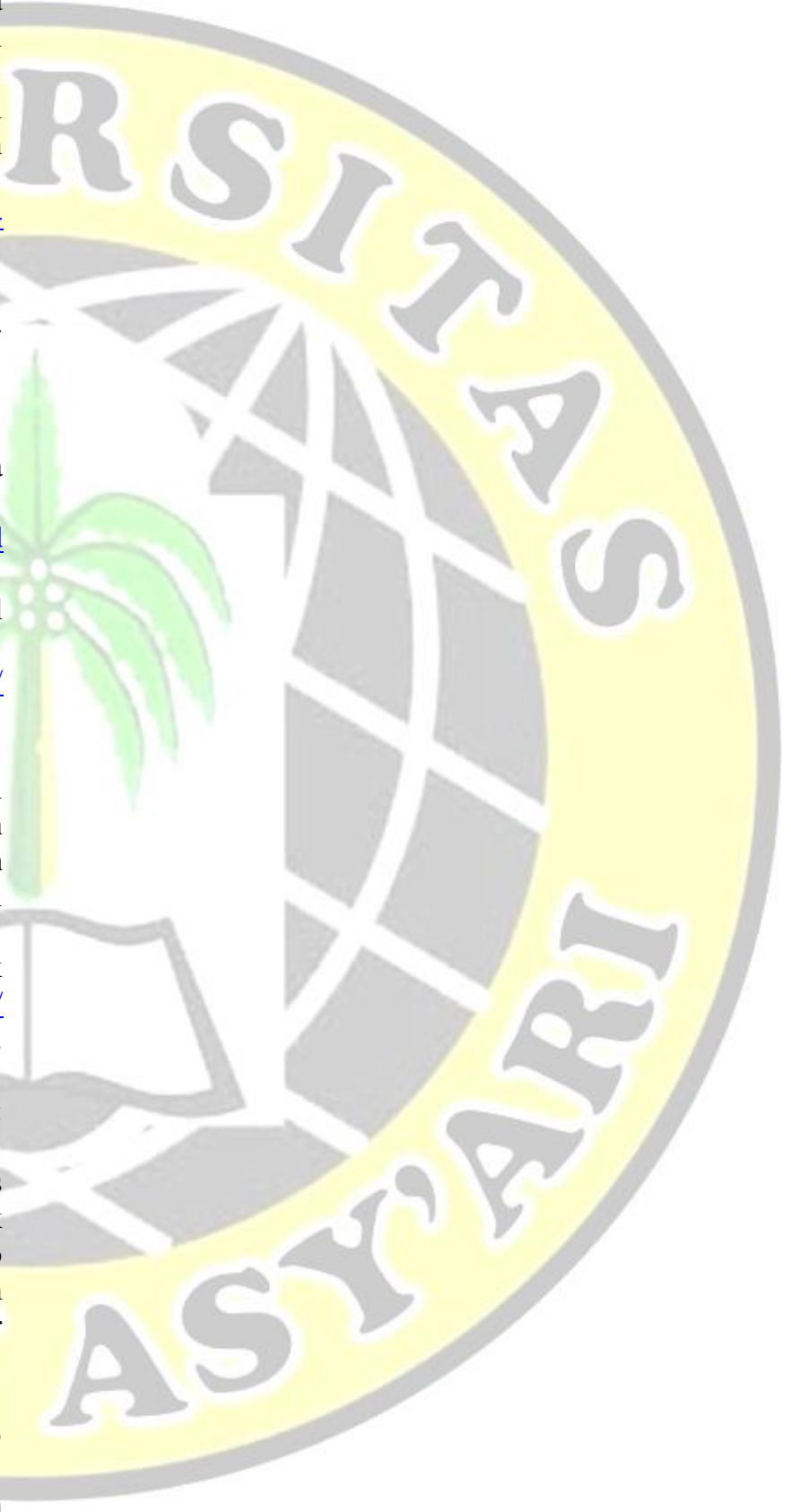

